\title{
Interaction of sodium nitrite and sunset yellow and its effect on some biochemical parameters in young albino rats
}

\author{
Eman G.E. Helal* and Mervat Abdel-Rahman** \\ * Zoology Department, Faculty of Science, Al-Azhar University (Girls) \\ ** Clinical Pathology Lab., Student Hospital, Cairo University, Giza
}

\begin{abstract}
Children usually eat and drink food containing both food preservatives, as sodium nitrite and food colourants, as sunset yellow (S.S.Y) at the same time. The mixture of the two agents at the limited dose of each was found to be lethal. $1 / 10^{\text {th }}$ of this dose was used daily for 30 days. Animals were divided into three groups. The first served as a control, while the second was orally administered a mixture of sodium nitrite $(\mathrm{NaNO} 3)$ and S.S.Y. The third received garlic in addition to the above mixture. Half of the animals from each group were decapitated after 30 days of treatment, while the other half was left for another 15 days for recovery. Investigation of the mixture of sod.nitrite and S.S.Y significantly decreases protein and albumin. Significant increases were observed in cholesterol, gamma-glutamyltranspeptidase (GGT), alkaline phosphatase (AP), lactate dehydrogenase $(\mathrm{LDH})$ and creatine phosphokinase (CPK). No change was observed for Total protein, Triglyceride, aspartate aminotransferase (AST), alanine aminotransferase(ALT) and acid phosphatase (AcP) recorded.

A complete recovery from the abnormalities of most biochemical parameters was observed after the recovery period or when garlic was administered. This draws attention to the dangers of interactions of such preservatives and colourants. The present study showed that even the permitted doses of colourants and food preservatives may be harmful. And illustrate that usage of garlic may ameliorate some of the expected hazards of food additions.
\end{abstract}

Key Words: Garlic, NaNO3, sunset yellow

\section{Introduction:}

Every food designer knows that consumers judge a product not only on its flavour, but on its appearance as well. One important class of ingredients exists solely to enhance the appearance of what we eat: food colours (Lindsay, 1985).

Sunset Yellow, a liquid crystal aggregated dye, meaning that the molecules tend to aggregate at sufficiently high concentration. It is used as a food colouring in foods including cereals and desserts. This chemical is also a colouring agent for dairy products, snack foods, jams, canned food, in gelatin, frozen desserts, carbonated beverages, dry drink powders, confectionary products, bakery products, puddings, maraschino cherries, pet food and sausages (U.S. Environmental protection Agency, 1986).
Sodium nitrite is an inorganic salt used in the manufacture of dyes and as a food additive that has been used for decades to preserve meats (HMSO, 1987), poultry and fish. More than 85 percent of a person's daily intake of nitrite comes from nitrate in green, leafy vegetables or root vegetables, such as lettuce, spinach and carrots, and some drinking water. At most, about 5 percent of a person's daily intake comes from cured meats. Some of the concern about nitrite grew out of the fact that nitrites could potentially react in the stomach with certain chemicals that are released during protein digestion to produce a chemical known as $\mathrm{N}$-nitrosamines. $\mathrm{N}$ nitrosamines has been associated with cancer in animals. There also were a number of studies during the 1970s that 


\section{Eman G.E. Helal \& Mervat Abdel-Rahman}

linked the consumption of nitrite with cancer in laboratory animals or associated the consumption of cured meats with illnesses in children. As a result of some lingering concerns about nitrite safety, the FDA and the USDA commissioned a comprehensive review of sodium nitrite's role as a food additive. The last two reactions are the free radical chain propagation steps. Disproportionation of two nitrogen dioxide radicals produces a nitrite anion, regenerates a nitrite anion, and constitutes the free radical chain termination step (Michael et al., 2002).

Some dyes naturally aggregate and form liquid crystal phases at a high enough concentration. Sunset Yellow, a liquid crystal aggregated dye, meaning that the molecules tend to aggregate at sufficiently high concentration. It is used as a food colouring in foods including cereals and desserts. This chemical is also a colouring agent for dairy products, snack foods, jams, canned food, in gelatin, frozen desserts, carbonated beverages, dry drink powders, confectionary products, bakery products, puddings, maraschino cherries, pet food and sausages. In addition to food, it is also used in aqueous drug solutions, tablets, capsules, tooth pastes, hair rinses and cosmetics. It is also used in making inks (U.S. Environmental protection Agency, 1986).

Garlic is one antioxidant that defends against free radicals damage, thereby preserving the body's healthy functioning (Hey B. 2002 and Banerjee et al. 2003). It contains sulphur compounds, such as allicin which is enhanced further when the garlic is chopped or crushed. The smell and taste of the garlic is due to the allicin compound (amino acid). This could be due to its antioxidant properties to fight free radicals. Studies have suggested that individuals who consume garlic on regular basis show lower incidence of stomach cancer, lower blood pressure, prevent blood clots and strengthen the body's immunity system (Fleishauer and Arab 2001, Nishino et al. 1989).

Helal (2001) decided that the limited dose of each NaNO3 and S.S.Y react together to give a lethal dose of new compound. This study is planned to illustrate this interaction and to use garlic to illustrate its effect on this new component.

\section{Material and methods}

Thirty young albino rats (weighing about 70-80g) were used in this study. Animals were housed in stainless steel cages, fed on rat chew and offered water. The animals were divided into three equal groups (10 rats each) as follows:

The first group: (control group),The second group: orally administered $10 \mathrm{mg}$ $\mathrm{NaNO} 3 / \mathrm{kg}$ and $0.5 \mathrm{mg}$ sunset yellow (S.S.Y) daily by gastric intubations for a month.

The third group: received $10 \mathrm{mg}$ NaNO3 $/ \mathrm{kg}$ and $0.5 \mathrm{mg}$ sunset yellow (S.S.Y) daily for a month + garlic $50 \mathrm{mg} / \mathrm{kg} / \mathrm{day}$.

After 30 days of treatment, 5 animals of each group were decapitated. While the other half was kept for two more weeks, without any additional treatment as a recovery period.

Blood samples were collected for biochemical parameters. Centrifuged for 15 min. at $5000 \mathrm{rpm}$ and supernatant sera were separated for analysis without storage or delay.

Total proteins were estimated using the Biuret method as described by Doumas (1975). Total lipids were determined according to the method of knight et al. (1972). Albumin was evaluated according to the method of Webster (1977), while serum cholesterol was determined as mentioned by Fossati and Medici (1987). AST and ALT activities were accomplished using the method of Reitman and Frankel (1975). Gamma-glutamyltanspeptidase was estimated by the method of Meister and Groffith (1981). While, lactic dehydrogenase (LDH) activity was determined according to Raabo (1963). CPK (creatinine-phospho-kinase) assay was performed using sigma chemical company reagent kits (st.louis Mo).

Triglycerides were determined by the method of Rojkin et al. (1974). Alkaline phosphatase activity was measured according to the method of Belfied and 
Goldberg (1971). And the activity of the plasma acid phosphatase was determined according to the methods of Tietz (1986).

Student t-test was used for comparison of data obtained for different parameters from different experimental animal groups. Significant differences between the means of control and treated groups were considered only at $\mathrm{p}<0.05$ (Sokal and Rohif, 1981).

\section{Results}

The data of serum total lipids, total cholesterol and serum triglycerides were shown in table (1). No significant difference between groups was observed in serum total lipids and serum triglycerides throughout the experimental period. On the other hand, serum cholesterol showed a significant increase $(p<0.05)$ in mixture treated rats after a month of treatment.

Table (2) showed total serum protein contents in control and in the two different treated groups. Total serum protein contents were significantly decreased $(\mathrm{p}<0.01)$ in the mixture treated group and dust treated group (mixture + garlic) after the treated period only. This increase turned back to the normal range in both groups after the recovery period.

Concerning the effect of the mixture on serum albumin (Table 2), the result revealed a significant decrease $(\mathrm{p}<0.01)$ after the treatment period. While significant increase $(\mathrm{p}<0.01)$ was recorded in the case of garlic and mixture treated group after the recovery period. Whereas, the level of serum globulin recorded insignificant changes after the treatment period followed by a significant decrease after the recovery period in the case of a mixture treated group. On the other hand, garlic treated group revealed insignificant change in serum globulin throughout the experimental period. A/G ratio recorded no significant change in all treated groups till the end of the experiment (Table 2).

The present results indicate that, serum AST and ALT activities were still within the normal values for all groups after the treated period (30 days) or the recovery period (15 days) in comparison with that of the control group (Fig. 1\&2).

Administration of both $\mathrm{NaNO} 3$ and S.S.Y increased $(p<0.01)$ serum activities of GGT, Cpk and alkaline phosphatase compared to those of the control till the end of the experiment (Figs 3,4 and 5). No significant changes of these enzymes activities were observed in the group given garlic. Furthermore, serum LDH activity exhibited a highly significant increase $(p<0.01)$ in food additives tread group after treated period only as compared with the control ones (Fig.6). However, no significant changes were recorded in serum acid phosphatase activity (Fig.7) in all groups. The administration of garlic showed insignificant changes of all the tested enzyme activities throughout the experiment.

The group treatment with both sodium nitrite and sunset yellow induced a significant increase $(\mathrm{p}<0.01)$ of serum glucose level, serum calcium level, inorganic phosphorus level, serum T3 and serum T4 level as compared with the control group (Table 3). When animals were administered garlic in addition to the mixture of additives, there was no significant change in serum glucose, serum calcium and serum T4. The data showed that it increased significantly for the inorganic phosphorus level $(\mathrm{p}<0.01)$ and serum T3 $(\mathrm{p}<0.05)$ in the group treated with $\mathrm{NaNO} 3+$ S.S.Y + garlic as compared with the control group (Table 3 ). 


\section{Eman G.E. Helal \& Mervat Abdel-Rahman}

Table (1): The effect of sodium nitrite, S.S.Y. and garlic on serum Total lipids, cholesterol and triglycride of albino rats after treated and recovery periods.

\begin{tabular}{|c|c|c|c|c|c|c|c|}
\hline \multirow[t]{2}{*}{ Parameters } & & \multicolumn{3}{|c|}{ Treated Period } & \multicolumn{3}{|c|}{ Recovery Period } \\
\hline & & Control & $\begin{array}{c}\text { NaNO+ } \\
\text { SSY }\end{array}$ & NaNO+SSY+garlic & Control & $\begin{array}{c}\text { NaNO+ } \\
\text { SSY }\end{array}$ & NaNO+SSY+garlic \\
\hline $\begin{array}{l}\text { Total lipids } \\
\mathrm{mg} / \mathrm{dl}\end{array}$ & $\begin{array}{c}\mathrm{x}+\mathrm{S} . \mathrm{E} \\
\mathrm{p}\end{array}$ & $388 \pm 4.8$ & $\begin{array}{c}396 \pm 5.1 \\
\text { N.S }\end{array}$ & $\begin{array}{c}362 \pm 14 \\
\text { N.S }\end{array}$ & $382 \pm 7.3$ & $\begin{array}{c}388 \pm 7.3 \\
\text { N.S }\end{array}$ & $\begin{array}{c}338 \pm 12 \\
<.05\end{array}$ \\
\hline $\begin{array}{c}\text { Cholesterol } \\
\mathrm{mg} / \mathrm{dl}\end{array}$ & $\begin{array}{c}x+S . E \\
p\end{array}$ & $131 \pm 4.5$ & $\begin{array}{c}150 \pm 4 \\
<.05 \\
\end{array}$ & $\begin{array}{c}116 \pm 8 \\
\text { N.S }\end{array}$ & $129 \pm 7.8$ & $\begin{array}{c}136 \pm 4 \\
\text { N.S }\end{array}$ & $\begin{array}{c}128.2 \pm 7 \\
\text { N.S }\end{array}$ \\
\hline $\begin{array}{l}\text { Triglycride } \\
\mathrm{mg} / \mathrm{dl}\end{array}$ & $\begin{array}{c}\mathrm{x} \pm \mathrm{S} . \mathrm{E} \\
\mathrm{p}\end{array}$ & $98 \pm 3.7$ & $\begin{array}{c}118 \pm 5.8 \\
\text { N.S }\end{array}$ & $\begin{array}{c}96 \pm 6.7 \\
\text { N.S }\end{array}$ & $90.8 \pm 1.7$ & $\begin{array}{c}99 \pm 3.5 \\
\text { N.S }\end{array}$ & $\begin{array}{c}93 \pm 4.3 \\
\text { N.S }\end{array}$ \\
\hline
\end{tabular}

Table (2): The effect of sodium nitrite, S.S.Y. and garlic on serum total protein, albumin, globumin and $\mathrm{A} / \mathrm{G}$ of albino rats after treated and recovery periods.

\begin{tabular}{|c|c|c|c|c|c|c|c|}
\hline \multirow[t]{2}{*}{ Parameter } & & \multicolumn{3}{|c|}{ Treated Period } & \multicolumn{3}{|c|}{ Recovery Period } \\
\hline & & Control & $\begin{array}{c}\mathrm{NaNO}+ \\
\text { SSY }\end{array}$ & $\mathrm{NaNO}+\mathrm{SSY}+$ garlic & Control & $\begin{array}{c}\text { NaNO+ } \\
\text { SSY }\end{array}$ & $\mathrm{NaNO}+\mathrm{SSY}+$ garlic \\
\hline $\begin{array}{c}\text { Total Protein } \\
\text { g/dl }\end{array}$ & $\begin{array}{c}\mathrm{x}+\mathrm{S} . \mathrm{E} \\
\mathrm{p}\end{array}$ & $8.34+.3$ & $\begin{array}{c}6.48 \pm .03 \\
<.01\end{array}$ & $\begin{array}{c}7.6 \pm .18 \\
<.01\end{array}$ & $7.9 \pm .16$ & $\begin{array}{c}7.78 \pm .19 \\
\text { N.S }\end{array}$ & $\begin{array}{c}7.6 \pm .19 \\
\text { N.S }\end{array}$ \\
\hline $\begin{array}{l}\text { Albumin } \\
\mathrm{g} / \mathrm{dl}\end{array}$ & $\begin{array}{c}\mathrm{x} \pm \mathrm{S} . \mathrm{E} \\
\mathrm{p}\end{array}$ & $5.54+.1$ & $\begin{array}{c}4.22 \pm .1 \\
<.01\end{array}$ & $\begin{array}{c}5.34 \pm .15 \\
\text { N.S }\end{array}$ & $4.9 \pm .14$ & $\begin{array}{c}4.84 \pm .09 \\
\text { N.S }\end{array}$ & $\begin{array}{c}5.24+.08 \\
<.01\end{array}$ \\
\hline $\begin{array}{c}\text { Globumin } \\
\mathrm{g} / \mathrm{dl}\end{array}$ & $\begin{array}{c}\mathrm{x}+\mathrm{S} . \mathrm{E} \\
\mathrm{p}\end{array}$ & $2.71 \pm .13$ & $\begin{array}{c}2.41 \pm .17 \\
\text { N.S }\end{array}$ & $\begin{array}{c}2.7 \pm .1 \\
\text { N.S }\end{array}$ & $3.1 \pm .1$ & $\begin{array}{c}2.6 \pm .18 \\
<.05\end{array}$ & $\begin{array}{c}2.42 \pm .1 \\
\text { N.S }\end{array}$ \\
\hline $\mathrm{A} / \mathrm{G}$ & $\begin{array}{c}\mathrm{X} \pm \mathrm{S} . \mathrm{E} \\
\mathrm{p}\end{array}$ & $2.04 \pm .1$ & $\begin{array}{c}1.98 \pm .18 \\
\text { N.S }\end{array}$ & $\begin{array}{c}2.14 \pm .16 \\
\text { N.S }\end{array}$ & $1.58 \pm .1$ & $\begin{array}{c}1.76 \pm .22 \\
\text { N.S }\end{array}$ & $\begin{array}{c}2.26 \pm .22 \\
\text { N.S }\end{array}$ \\
\hline
\end{tabular}

Table (3): The effect of sodium nitrite, S.S.Y. and garlic on glucose, calcium, inorganic phosphorus, T3 and T4.

\begin{tabular}{|c|c|c|c|c|c|c|c|}
\hline \multirow[t]{2}{*}{ Parameter } & & \multicolumn{3}{|c|}{ Treated Period } & \multicolumn{3}{|c|}{ Recovery Period } \\
\hline & & Control & $\begin{array}{c}\mathrm{NaNO}+ \\
\text { SSY } \\
\end{array}$ & $\mathrm{NaNO}+\mathrm{SSY}+$ garlic & Control & $\begin{array}{c}\text { NaNO+ } \\
\text { SSY } \\
\end{array}$ & NaNO+SSY+garlic \\
\hline $\begin{array}{c}\text { Glucose } \\
\mathrm{mg} / \mathrm{dl}\end{array}$ & $\begin{array}{c}\mathrm{x} \pm \mathrm{S} . \mathrm{E} \\
\mathrm{p}\end{array}$ & $93.6 \pm 2$ & $\begin{array}{c}134.4 \pm 1.9 \\
<.01\end{array}$ & $94.4 \pm 1.6$ & $92.4 \pm 1.7$ & $\begin{array}{c}105.4 \pm 1.7 \\
<.01\end{array}$ & $89.8 \pm 2.7$ \\
\hline $\begin{array}{c}\text { Calcium } \\
\mathrm{mg} / \mathrm{dl}\end{array}$ & $\begin{array}{c}\mathrm{x} \pm \mathrm{S} . \mathrm{E} \\
\mathrm{p}\end{array}$ & $7.9 \pm .2$ & $\begin{array}{c}9.9 \pm .2 \\
<.01 \\
\end{array}$ & $7.76 \pm .2$ & $7.5 \pm .18$ & $\begin{array}{c}8.7 \pm .2 \\
<.01\end{array}$ & $7.9 \pm .18$ \\
\hline $\begin{array}{l}\text { Inorganic phosphorus } \\
\mathrm{mg} / \mathrm{dl}\end{array}$ & $\begin{array}{c}\mathrm{x} \pm \mathrm{S} . \mathrm{E} \\
\mathrm{p}\end{array}$ & $12.04 \pm .18$ & $\begin{array}{c}9.9 \pm .2 \\
<.01 \\
\end{array}$ & $\begin{array}{c}11 \pm .2 \\
<.01 \\
\end{array}$ & $11.94 \pm .18$ & $\begin{array}{c}10.8 \pm .2 \\
<.01 \\
\end{array}$ & $11.68 \pm .19$ \\
\hline $\begin{array}{c}\mathrm{T} 3 \\
\mathrm{mg} / \mathrm{dl}\end{array}$ & $\begin{array}{c}\mathrm{x} \pm \mathrm{S} . \mathrm{E} \\
\mathrm{p}\end{array}$ & $166 \pm 1.8$ & $\begin{array}{c}189 \pm 1.8 \\
<.01\end{array}$ & $\begin{array}{c}160 \pm 1.5 \\
<.05\end{array}$ & $157.8 \pm 1.1$ & $\begin{array}{c}168.8 \pm .9 \\
<.01\end{array}$ & $163.6 \pm 2.7$ \\
\hline $\begin{array}{c}\mathrm{T} 4 \\
\mathrm{mg} / \mathrm{dl}\end{array}$ & $\begin{array}{c}\mathrm{x} \pm \mathrm{S} . \mathrm{E} \\
\mathrm{p}\end{array}$ & $7.64 \pm .3$ & $\begin{array}{c}9.5 \pm .1 \\
<.01\end{array}$ & $7.28 \pm .1$ & $6.84 \pm .09$ & $\begin{array}{c}7.4 \pm .1 \\
<.01\end{array}$ & $7.02 \pm .3$ \\
\hline
\end{tabular}


Interaction of sodium nitrite and sunset yellow and.........

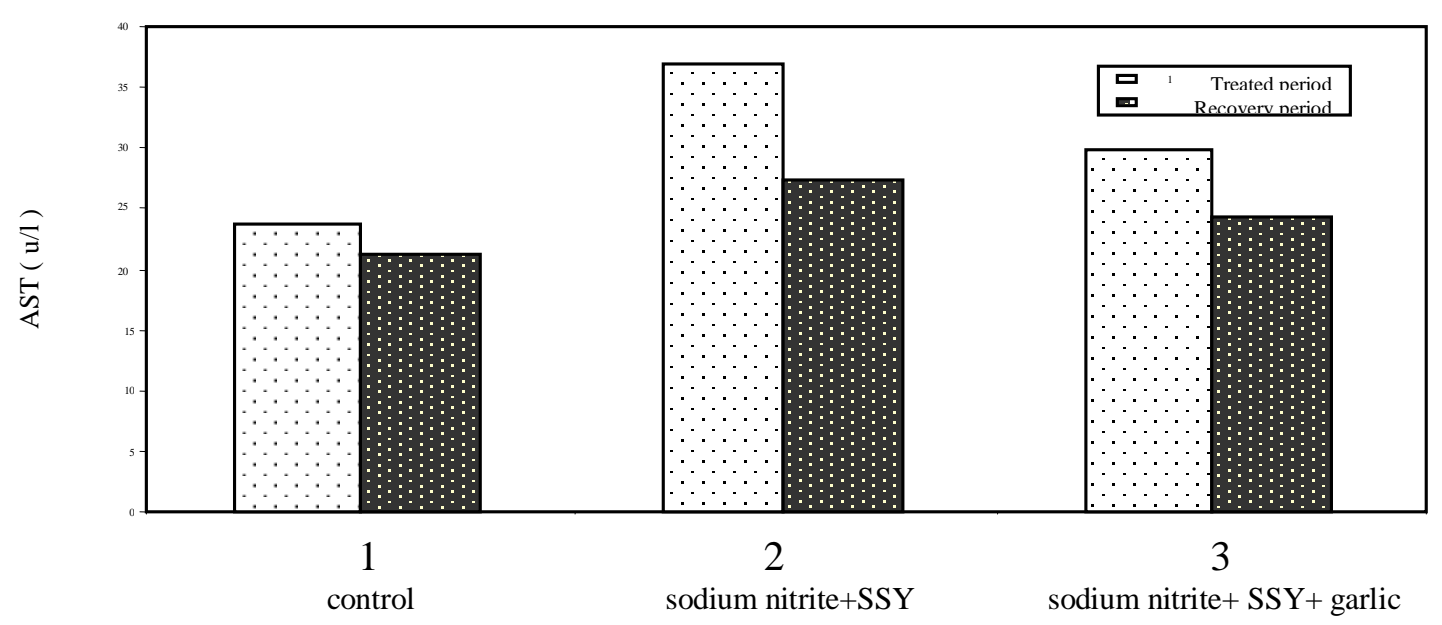

Fig.(1): The effect of sodium nitrite, S.S.Y. and garlic on serum AST activity (u/l)

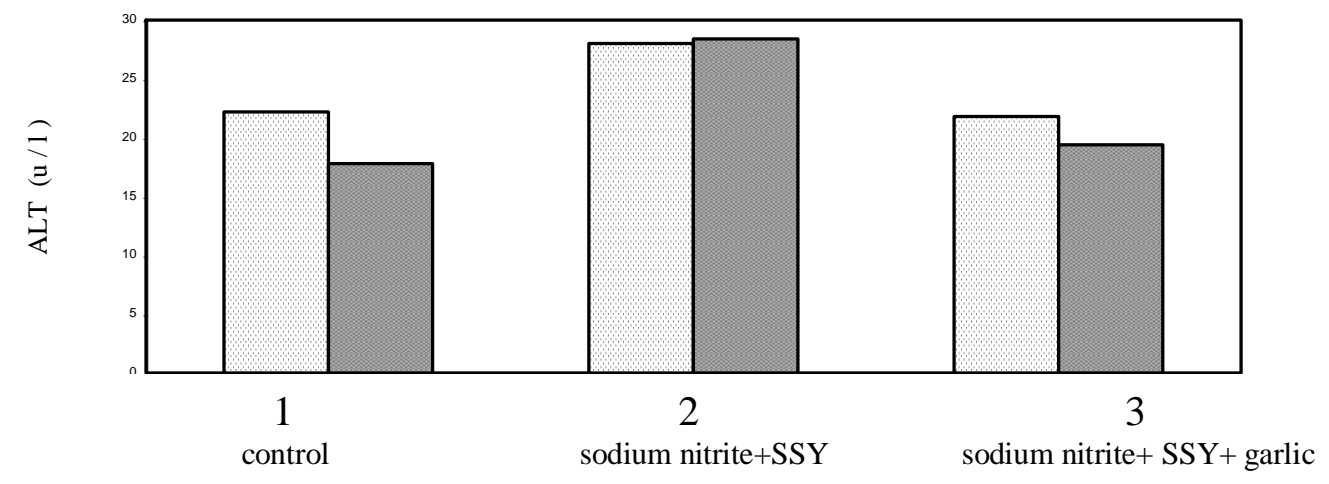

Fig.(2): The effect of sodium nitrite, S.S.Y. and garlic on serum ALT activity (u/l).

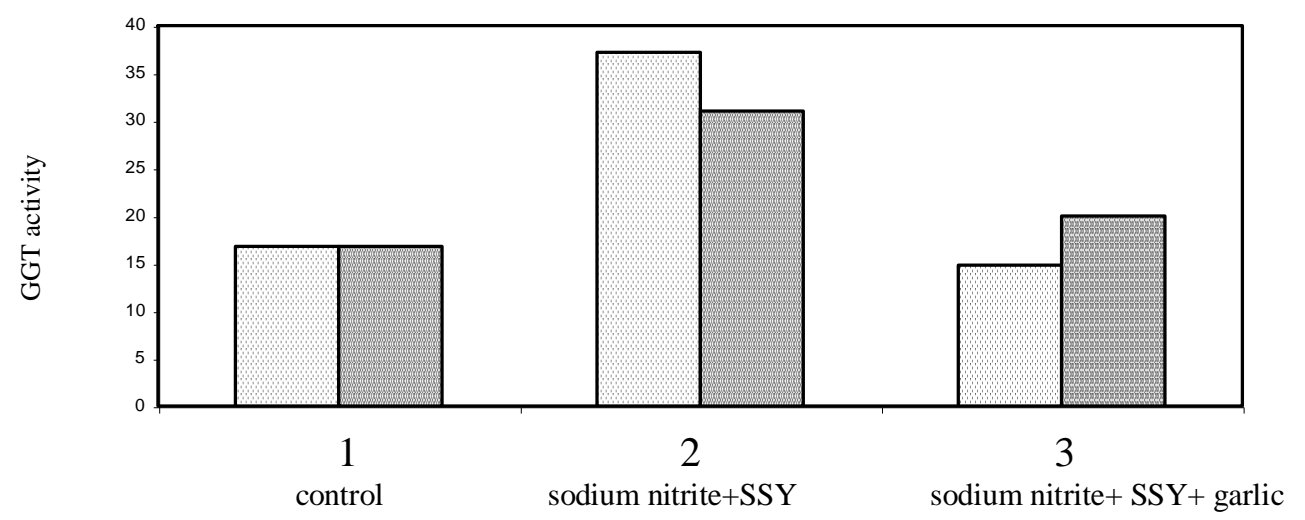

Fig.(3): The effect of sodium nitrite, S.S.Y. and garlic on serum GGT activity. 


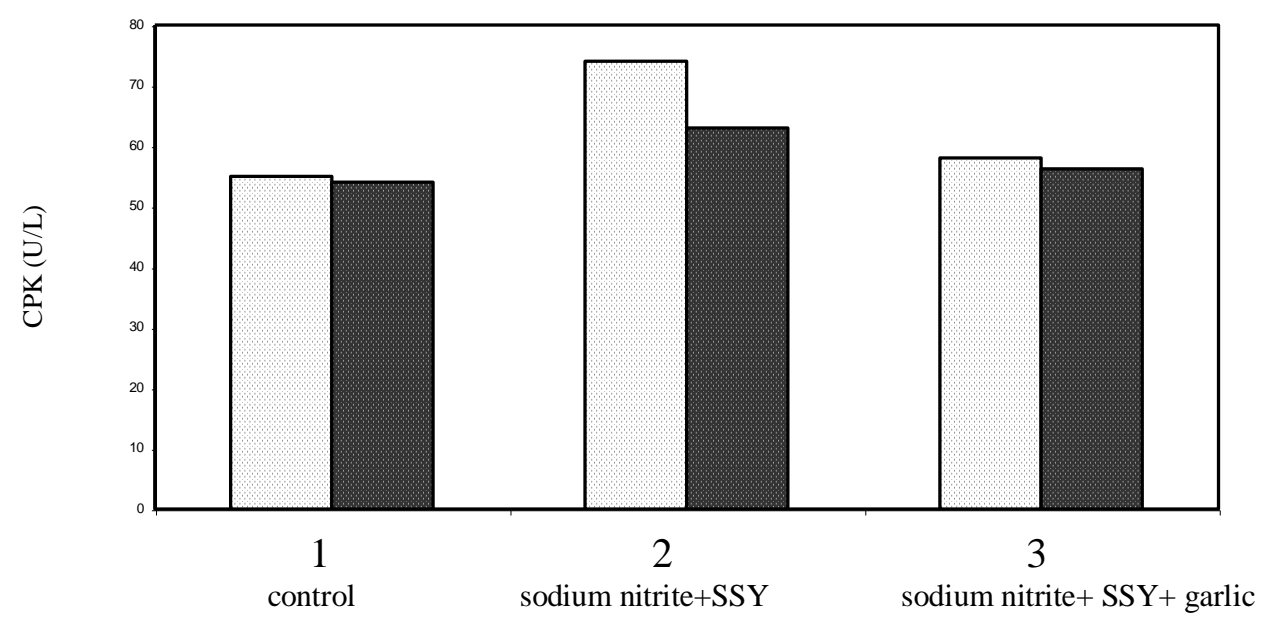

Fig.(4): The effect of sodium nitrite, S.S.Y. and garlic on serum CPK (U/L).

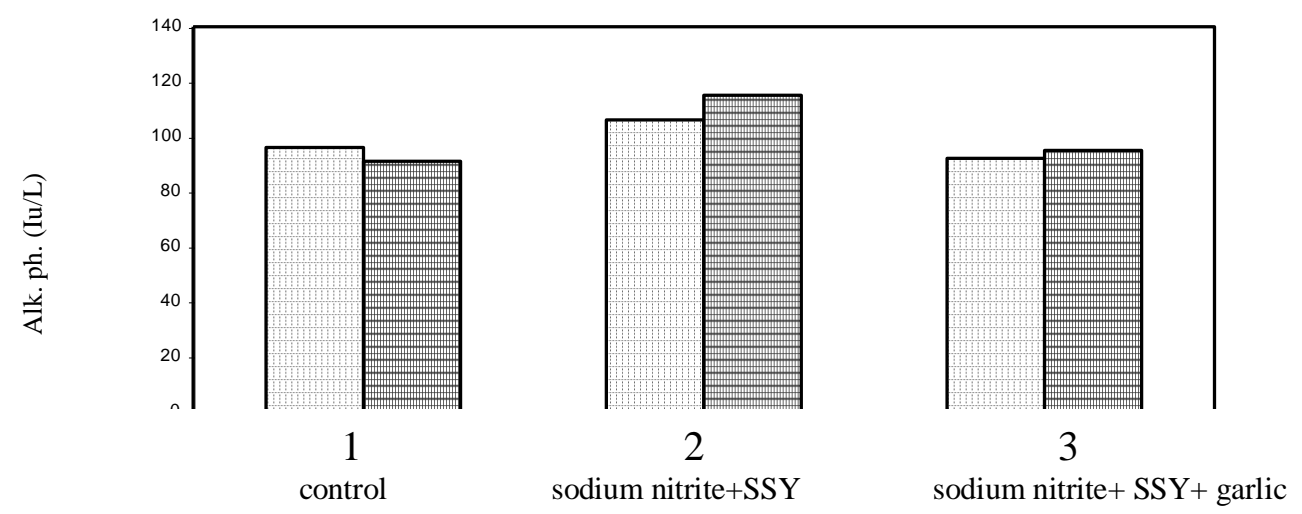

Fig.(5): The effect of sodium nitrite, S.S.Y. and garlic on alkaline phosphatase(P).

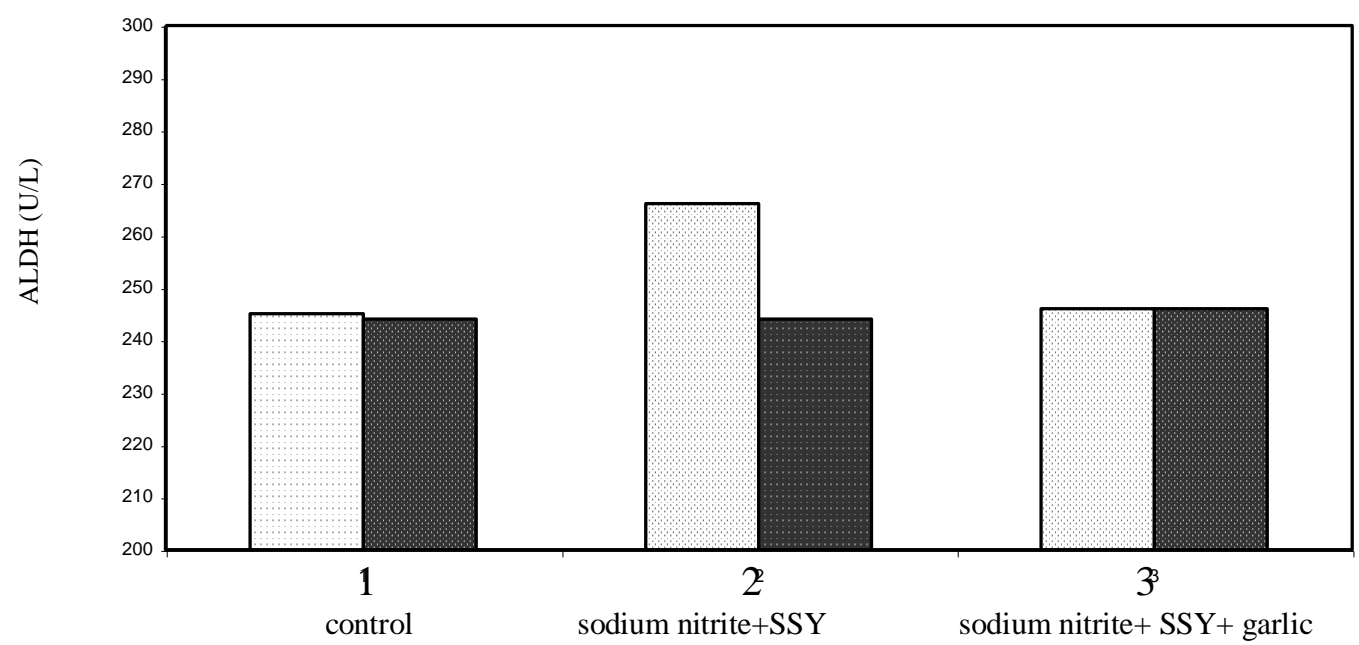

Fig.(6): The effect of sodium nitrite, S.S.Y. and garlic on serum LDH (U/L). 


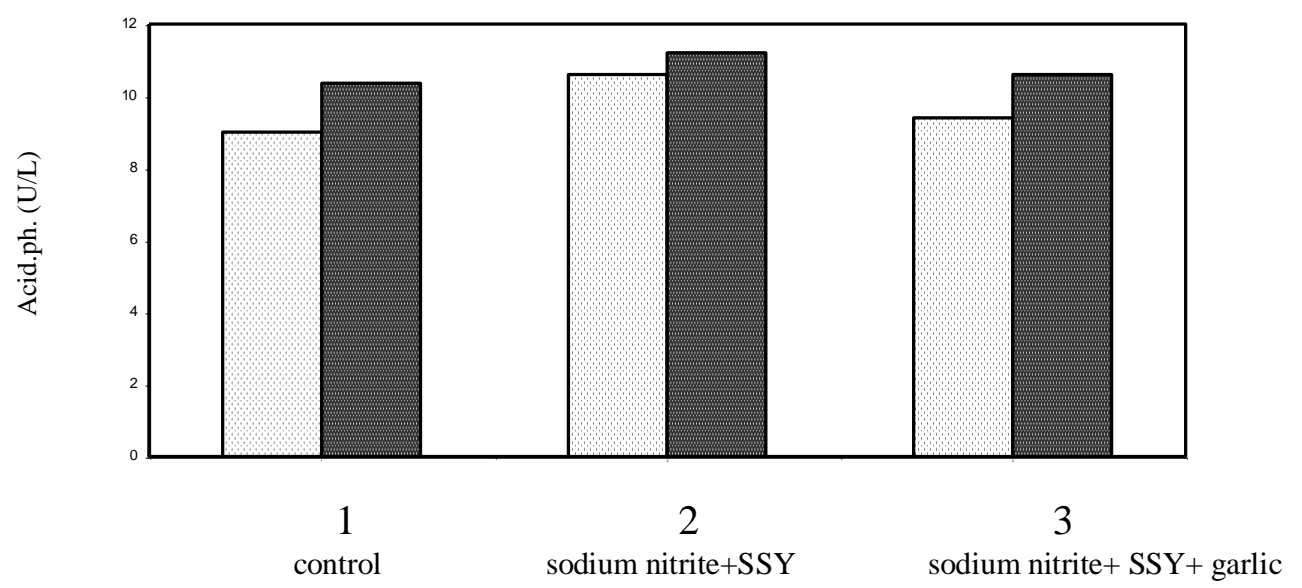

Fig.(7): The effect of sodium nitrite, S.S.Y. and garlic on acid phosphatase(AcP)

\section{Discussion:}

Many studies have been carried out to establish the role of food colourants in children hyper activity. Later, other studies reported that daily intake of a mixture of food colourants can produce measurable changes in the behavior of a group of children (Wender 1980, Lipton 1983 and Pollock and Warner 1990). Adding a limited dose of food additives to each other may produce a new toxic material (Helal, 2001). In the present investigation we followed up the last study and used garlic as a natural product to study its role as a protective material. No significant changes occurred in the level of serum total lipids and serum triglyceride of rats treated with the mixture alone or the mixture and garlic throughout the experiment. Similar results obtained in case of serum triglycerides. Cholesterol is the most abundant steroid in the cells of higher animals. It is considered an essential structural component of cell membrane (Thorpe et al., 1964). In the present study, serum cholesterol was increased significantly $(\mathrm{p}<0.05)$ in the group treated with a mixture $(\mathrm{NaNO} 3+$ S.S.Y) in comparison with control rats, while no significant changes were observed in rats treated with garlic in addition to the mixture. When reducing agents such as garlic or ascorbic acid were added to the diet, serum cholesterol was fallen (Angelis et al., 1996). The authors suggested that the adverse effects of nitrate diet may occur in relation to peroxidation. This suggestion may support the findings of Bruning-Fann and Kaneene (1993) where, they found that nitrate ingestion in monogastric animals has been linked to interference with the metabolism of other antioxidants than garlic such as ascorbic acid, vitamins $\mathrm{A}$ and $\mathrm{E}$. Hence, the increased level of serum cholesterol noted here in rats exposed to the mixture could be attributed to the peroxidation of cell membrane lipids (Standberg, 1977). So, a current evidence indicated that nitrites act as cell membrane oxidants (Beaupre and Schiffman, 1994).

A significant decrease of the total serum protein was recorded $(\mathrm{p}<0.01)$ after treatment with the mixture of $\mathrm{NaNO} 3$ and S.S.Y for one month. The decrease of total serum protein due to the mixture treatment was reflected on serum albumin level where a remarkable decrease was recorded. It is suggested that this decrease of albumin resulted from liver function impairment induced by the nitrite. The globulin fraction, on the other hand, was not affected generally at the same time, but it was affected after the recovery period. Garlic plus the mixture treatment lead to a decrease in globulin all over the 


\section{Eman G.E. Helal \& Mervat Abdel-Rahman}

experimental time and an increased $\mathrm{A} / \mathrm{G}$ ratio after the recovery period.

The harmful effect of nitrite is reflected on the biosynthesis of protein as reported by Eremin and Yocharina (1981). They found that serum protein of rats are decreased due to the stimulatory effect of the nitrite on the thyroid and adrenal glands that leads to block of protein synthesis while fast breakdown occurs. This leads to an increase of free amino acids and to a decrease of protein turnover (Yanni et al., 1991). Furthermore, sodium nitrites have been reported to produce retardation of growth (Atef et al., 1991), necrotic changes of the liver and deterioration of the liver function and renal tubules (Anthony et al., 1994; El-Bllal et al., 1994; Guler et al., 1994 and Rodriguez-Morona and Tarazona, 1994), reduction of myocardial GSHPX, gastric function and alteration of gastric mucosal absorption and decreased food consumption (Burning-Fann and Kaneene, 1993 and Hirose et al., 1993).

However, it is clear that sodium nitrite decrease total serum proteins and albumin mainly through its effect on the liver through inhibiting oxidative phosphorylation process and hence the availability of the energy source of protein synthesis (Anthony et al., 1994) and other metabolic processes or through the necrotic changes especially of the plasma membrane (Guler et al., 1994). At the same time, the nitrite effects on the process of reabsorption in the kidney tubules and impaired absorption of digested food material cannot be ignored. Rodriguez-Morona and Tarazona (1994) indicated that uronyl nitrate decreases proximal tubular reabsorption which results in the activation of glomelular feed-back and lowers nephron filtration rate. Also, these results find good support in the study carried out by Helal et al. (2000) who illustrated a marked decrease of serum protein in rats after treatment with sunset yellow or carmine. Furthermore, it is conceivable to assume that garlic may exert a protective role against the mixtureinduced toxicity. Evidence of this view in the present findings is that garlic treatment of the mixture-intoxicated rats resulted in an increase of total serum proteins. This effect probably reflects the ability of garlic to protect the protein manufacturing machinery from the mixture-induced cellular damage.

Many enzymes like alkaline phosphatase (AP) and GGT tend to be released into plasma in large amounts following the hepatocellular damage. Gamma glutamyle transferase is considered to be more specific for liver function tests. Its activity is markedly increased in plasma in both primary and secondary carcinoma of liver. In the present work, both GGT and AP were increased in the group of rats given (NaNO3+S.S.Y). However, the significant reduction in GGT and AP activities in garlic treated group may be due to the good effect of the garlic to improve the activity of liver cells or to stop the damage of liver cell membranes and hence the release of their enzymes. The insignificant changes in AST and ALT activities in all treated groups may be due to the reason that their activities are less sensitive than GGT.

The effect of the mixture of $\mathrm{NaNO} 3$ and S.S.Y on serum enzyme activities (LDH and CPK) in this study provides further evidence on the effect of this mixture on the muscle and heart. This elevation could be attributed to a generalized increase in membrane activity (Doran and Wilinson, 1975). The present study showed a significant increase in serum LDH activity indicating cellular damage. Morlier et al. (1991) reported that increased lipid peroxidation is accompanied by the release of LDH reflecting membrane damage. Rybczynska et al. (1996) found that lipid peroxidation of cell membranes is associated with inactivation of membrane bound enzymes. Based on these molecular events, it is possible to explain systemic and metabolic responses evidenced in the present study by elevated activity of serum LDH as well as increased contents of cholesterol, in addition to a drop in total protein content of a mixture (NaNO3+S.S.Y) treated rats, which were reduced to reach normal levels after treatment with garlic.

The present results go in parallel with those reported on the hyperglycemic effect 
of sodium nitrite in rats (Abdel-Rahim et al, 1993 and Shelpov et al., 1991). They reported that in presence of nitric ion, the activity of amylase increases beside an inhibition of adrenaline-induced activation of phosphorylase. This results in the liberation of glucose from glycogen, so blood glucose increases while liver glycogen decreases.

The elevation of level of serum glucose was also interpreted by the effect of sunset yellow on enzyme system of glycolytic pathway. It is not surprising to find an enhanced hyperglycemia due to the new compound resulted from the reaction of sodium nitrite and sunset yellow treatment of the rats. The observed improvement shown in glucose in garlic treated group may be due to its action as antioxidant.

The result of this study demonstrated that the administration of $(\mathrm{NaNO} 3+\mathrm{S} . \mathrm{S} . \mathrm{Y})$ caused a significant increase $(p<0.01)$ in serum calcium level. This observation was similarly recorded by Sharma (1989), who recorded higher values of minerals in rats treated with metanil yellow. On the other hand, the present results showed a significant decrease in serum phosphatase after treatment with the mixture of $(\mathrm{NaNO} 3$ + S.S.Y) during the treated period, while after the recovery period it turned back to the normal value in garlic treated group. Helal et al. (2000) stated that S.S.Y did not affect serum level of both $\mathrm{Ca}$ and $\mathrm{Ph}$. So, the present results may be due to the new compound resulted from the reaction between both NaNo3 and S.S.Y.

In the current study, the mechanism by which sodium nitrite altered thyroid function is still uncertain. It could be proposed that nitrite may enhance intrathyroidal synthesis of thyroid hormones and increases the extrathyroidal conversion of T3 and T4. Meanwhile, nitrites may attenuate the binding capacity of thyroid binding proteins for thyroid hormones (Heibashy and Abd El-Moneim, 1999).

The present study revealed that administration of sod. nitrite and sunset yellow to rats caused variable degree of stimulation of thyroid gland function after treated and recovery periods. This was proved by the significant increase in serum thyroid hormones T3 and T4. The interaction between sod. nitrite and sunset yellow may give a new chemical component, which has a stimulatory effect on thyroid gland. It is also

clear that garlic ameliorates this effect due to its antioxidant property. This could be by blocking the generation and propagation of free radicals.

The present study throw the light on the damage role of some additives interaction. Even if they are used in the permitted dose. Knowing that in Egypt there is sometimes uncontrolled use of different food additives particularly in food consumed mostly by children, hence the safe use of different interactions of food additives should be investigated.

Amelioration of different hazards in rats supplemented with garlic substantiates our conclusion that garlic can counteract the toxic effect of these compounds. Basing on the present data we advice the addition of garlic in children's food.

\section{References:}

1. Abdel-Rahim, E.A. Ashoush; Y.A.; Afify, A.S. and Hewedi, F. (1993): Effect of some synthetic food additives on blood haemoglobin and liver function of rats. Minufiya J. Agric. Res., 12 (1): 557.

2. Angelis, R.C-DE; Terra, I.C.M; Scialfa, J.H. and Klemps, F.I. (1996): Dietary nitrite and scavenger antioxidants trace elements. Inter. J. Food sci. Nutr., 47: 23-26.

3. Anthony, M.L.; Gartland, K.P.; Beddell, C.R.; Lindon, J.K. (1994): Studies on the biochemical toxicology of uranyl nitrate in the rat. Arch. Toxicol., 68 (1): 43-53.

4. Atef, M.; Abo-Norage, M.A.; Hanafy, M.S. and Agag, A.E. (1991): Pharmacotoxicological aspects of nitrate and nitrite in domestic fowls. Br. Poult. Sci., 32 (2): 399404.

5. Banerjee, SK; Mukherjee, P.K. and Maulik, S.K. (2003) Garlic as an Antioxidant, Phytother Res. 17 (2): 97-106.

6. Beaupre, S.R. and Schiffman, F.J. (1994): Rush hemolysis, a bile cell hemolytic anemia associated with volatile 
liquid nitrite use. Arch. Fam. Med. 3: 545548.

7. Bellfield, A. and Goldberg, D.M. (1971): Hydrolysis of adenosine-monophosphate by acid phosphatase as measured by continuous spectrophotometric assay. Enzyme, 12: 561.

8. Bruning-Fann, C.S. and Kaneene, J.B. (1993): The effect of nitrate, nitrite and Nnitroso compounds in animal health. Vet. Hum. Toxicol., 35 (3): 237-253.

9. Doran, G.R. and Wilinson, J.H. (1975): The origin of the elevated activities of creatin kinase and other enzymes in the sera of patients with myxoedema. Clin. Chem. Acta., 62: 203.

10. Doumas, B.T. (1975): Standards for total serum protein assays. A collaborative study. Clin. Chem., 21 (8): 1159-1161.

11. El-ballal, S.S.; Ezzo, O.H.; Shalaby, S.I. A and Fawzy, Y. (1994): Sodium nitrite toxicity in Barki sheep. Egypt. J. of comparative pathology and Clinical pathology. 7 (2): 353-361.

12. Eremin, Y.N and Yochorina, M.G. (1981): Effect of nitrites on the thyroid gland of rats in response to different diets of iodine deficiency. Vopr. Pitan. 5: 60-62.

13. Fleischauer A.T, Arab L. (2001) Garlic and Cancer: A critical review of the epidemiological literature. J. Nut, 131: 1032-1040.

14. Fossati, P- and Medici, R. (1987): Abstract book: International symposium on cholesterol control and radiovascular diseases: Prevention and Therapy. Milan. Italy.

15. Guler, A.H.; Sapan, N.; Ediz, B.; Genc, Z. and Ozkan, K. (1994): Effect of copper on liver and bone metabolism in malnutrition. Turkish, J. Pediat., 36 (3): 205-213.

16. Heibashy, M.I.A. and Abd El-Moneim, A.E. (1999): Blood lipid profile and serum free thyroidal hormone concentrations in growing rats fed diets enriched with sodium nitrite for short and long terms. J. Egypt. Ger. Soc. Zool., 30 (A): 93-103.

17. Helal E.G.E. (2001) Progressive effect of the interaction of sodium nitrite and sunset yellow on different physiological parameters in albino rats. Egyptian J. of Hospital Medicine 2: 23-46.

18. Helal, E.G.E.; Zahkouk, S.A, $M$ and Mekawy, H.A. (2000): Effect of some food colours (synthetic and natural products) on liver and kidney functions of young albino rats. The Egyptian Journal of Hospital Medicine.

19. Hey B. (2002) Aged Garlic: A Potent Antioxidant, Issue of Natural Food Merchandiser, 1-2.

20. Hirose, M.; Tanaka, H.; Takahashi, S.; Futakuchi, M.; Fukushima, S. and Ito, N. (1993): Effects of sodium nitrite and catechol in a rat multiorgan model. Cancer Res. 53 (1): 32-37.

21. H.M.S.O (Her majesty's stationary office, London). (1987): Food additives. The balanced approach. Cited in: Food additives intolerance in childhood (1994) p.180.Black well scientific. LondonBoston.

22. Knight, J.A.; Anderson, S. and Rawle, J.M. (1972): Chemical basis of the sulfophosphovanillin reaction for estimation total serum lipids. Clin. Chem., 18 (3): 199-202.

23. Lindsay, R.C (1985): Food additives in fennema. Cited in: Food additives Intolerance in childhood. P.179. Ed. David, T.J. Blackwell scientific. London- Boston.

24. Lipton A.M (1983): Diet and hyperkinesis, and update. J.Am Diet Assoc. 83 (2): 13234.

25. Meister, A.S.S. and Groffith, O.W. (1981): Gammaglutamyl transpeptidase. Method Enzymol., 77: 237-253.

26. Micheal, C.; Kohn Ronald, L.; Frankye and Christopher J. Portier (2002): Pharmac-okinetics of Sodium NitriteInduced Methemoglobinemia in the Rat. DMD, 30: 676-683.

27. Morliere, P.; Moysan, A.; Santus, R.; Huppe; J.C. and Dubertret, L. (1991): UVA-induced lipid peroxidation in cultured human fibroplasts. Biochem. Biophy. Acta. 1084: 261-268.

28. Nishino, H.; Iwashima, A.; Itakura, H.; Matsuura, T.; and Fuwa, T. (1989) Antitumor promoting activity of garlic extracts. Oncology, 46: 277-280.

29. Pollock I. And Warner J.O. (1990): Effect of artificial food colours on childhood behavior. Arc. Dis. Child, 65: 74-77.

30. Raabo, E. (1963): Determination of serum lactic dehydrogenas by the tetrazolium salt method. Scard. J. Clin. And Lab. Invest., 15: 233.

31. Reitman, S. and Frankel, S. (1975): A colourimetric method for the determination of serum glutamic oxaloacetic and glutamic pyrovic transaminases. Am. J. Clin. Path., 28: 56. 
32. Rodriguez-morona, P.A. and Tarazona, J.N. (1994): Nitrite-induced methemoglobin formation and recovery in rainbow trout at high chloride concentrations. Bull. Environ. Contam. Toxicol. 53 (1): 113-139.

33. Rojkin, M.L.; Olguin, D.E.; Mariani, M.C.; Drappo, G.A.Y. and Sosa, C.P. (1974): Proteinastotales del sureo: causes mas Frecuentes de error en la roaccion del Biuret Nuevo reactivo cupraol calino estable. Biog. Del. Atlantico, V.11631193.

34. Rybczynska, M.; Hoffman, S. and Goslar, J. (1996): Molecular changes in erythrocyte membranes induced by nitroimidazoles and radiation. Pol. J. Pharmacol., 48: 269-280.

35. Sharma, S.D. (1989): Renal gross biochemistry of albino rat influenced by a common food color, metanil yellow. J. Adv. Zool., 10 (2): 95-98.

36. Shelpov, V.; Chekulaev, V. and PashaZade, G. (1991): Factors within the body determining the glycogen reserves in the tissues of rats. Biomed. Sci., 2 (2): 111-120.
37. Sokal, R.R. and Rohif, F.J. (1981): Biometry: The principles and practice of statistics in biological research. $2^{\text {nd }}$ ed. Freeman, W.H. Company San Francisco.

38. Standberg, A.S. (1977): Nitrate and nitrite supply and metabolism in man. (Abstract) Nutr. Abs. Revs. Ser (A), 47: 1119.

39. Thorpe, W.V; Bary, H.G. and James, S.P. (1964): "Biochemistry for medical students" $8^{\text {th }}$ Ed.J. and A. Churchill L.T.D, London, P.80.

40. Tietz, N.W. (1986): Text book of clinical chemistry, W.B. Saunders Co., London, Philadelphia.

41. Webster,D. (1977): Albumin standards and measurement of serum albumin with bromochresol green. Clin. Chem., 23: 663-666.

42. Wender E.H. (1980): New evidence on food additives and hyperkinesis. Am. J. Dis. Child, 134: 1122-24.

43. Yanni,M.;Abdel-Dayem,S.M. and AbdelAzim, B.H. (1991): Biochemical and Histological changes due to preser-vatives in rats. Egypt.J.Histol.; 14 (2): 431-440. 


\section{تفاعل نيتريت الصوديوم وصن ست الأصفر وتأثيرهما على بعض المعايير البيوكيميائية في الفئران البيضاء}

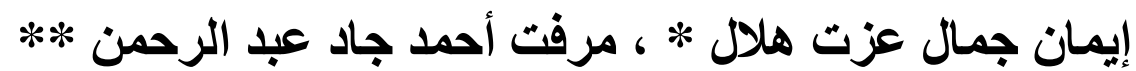

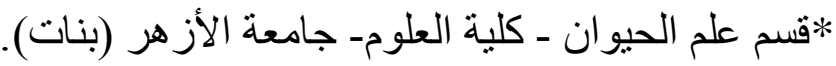

** * معمل الباتولوجيا الاكلينيكيةــ مستشفى الطلبة. جامعة القاهرةـ الجيزة.

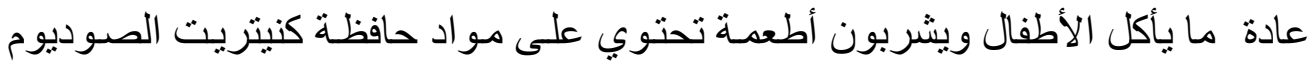

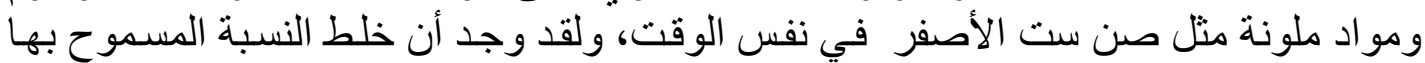

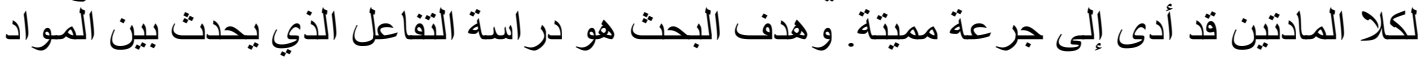

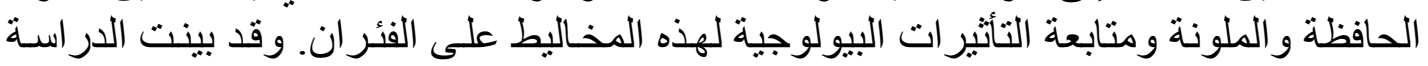

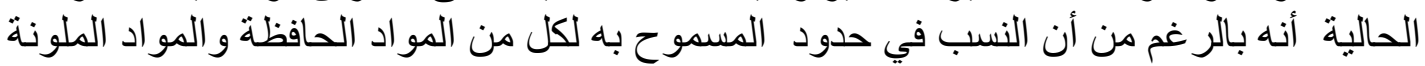

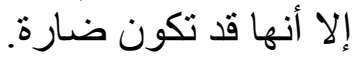
ولقد نم استخدام عشر قيمة الجر عة على الفئر ان لمدة ثلاثين يوماً وقد قسمت الحيو انات إلى

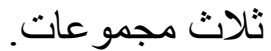

المجمو عة الأولى كمجموعة ضـابطة بينما جر عت المجموعة الثانية خليط من نبتريت

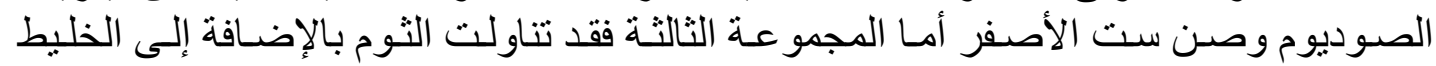

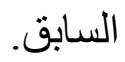
تم ذبح نصف المجاميع بعد ثلاثين يوماً وترك النصف الآخر لمدة 15 يومـاً أخرى كفترة استشفاء.

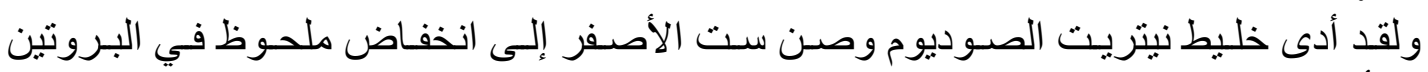

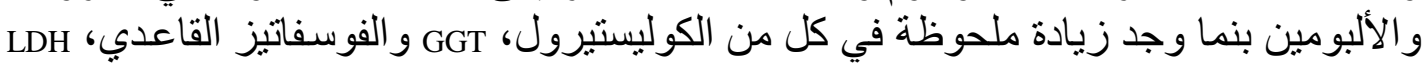

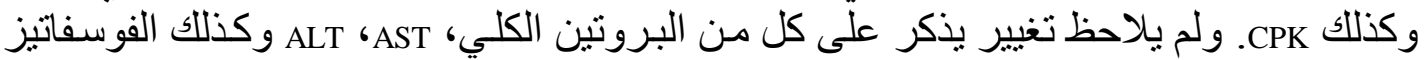
ولقد لوحظي. أنه تم الثفاء من أغلب هذه الإضطر ابات البيوكيميائية بعد فترة الإستشفاء وكذلك

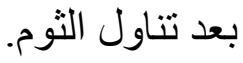

